\title{
AN ECOCRITICAL ANALYSIS OF YOUNG ADULT DYSTOPIAN NOVEL IN VERONICA ROSSI'S UNDER THE NEVER SKY
}

\author{
Rofi'atul Azizah, Sufi Ikrima Sa'adah \\ UIN Sunan Ampel Surabaya, UIN Sunan Ampel Surabaya \\ rofiq.azizah@gmail.com, sufi ikrima@yahoo.com
}

\begin{abstract}
This study aims to describe the representation of nature and the interaction of Aria and Peregrine as main characters with nature. Descriptive qualitative method is used by applying Garrad's theory of ecocriticism and Basu's perspective on dystopian literature. The results of this study are: first, pastoral is represented by the distiction of the town and country. In the novel town is reprsented as Reverie and country as Death Shop. Second,Wilderness is represented by the wilderness of society inthe Reverie and Death Shop and the wilderness of Death Shop's land. Third, Apocalypse is represented by the portrayal of foreboding doom and human eradication in the novel. The setting of place and time is the result of natural disaster and the development of technology takes control in human's life. The interaction of Aria and Peregrine shows human coexist with nature, human takes experience, learns knowledge and makes relation with nature.
\end{abstract}

Keyword: Nature; Dystopian; Ecocriticism; Young Adult Novel.

\section{INTRODUCTION}

Environment becomes one of the trending topics during the last decade. The rapid development of technology and industry in the age of globalization creates lots of problems such as air pollution, drought, soil erosion, and water contamination. The consequences of the destruction of nature will have an adverse effect on human survival and natural disaster for exampleearthquakes, volcanic eruptions, tsunamis, and storms. By this case, experts put forward their concerns through writing form so that books and novels about environment grow rapidly. Then, the study about environment is formed as one of the literary criticisms. It is called Ecocriticism. In The Ecocriticism Reader: Landmark in Literary Ecology, Cheryll Glotfelty and Harold Fromm (1996) explain ecocriticism as the study of the relationship between literature and the physical environment:

The portrait of ecocriticism also appears in dystopian literary texts. The dystopian is a bad place to live which the threat of environmental destruction due to ecological destruction like rising sea levels, storms, drought, and the end of fossil fuels create social, political, and economic nightmares (Basu et al, 2013:3). The environmental dystopian literature illustrates 
the dangers of environmental ruin and young-survivor protagonists learn to adapt in the hard times.

Under the Never Sky is a young adult dystopian novel which discusses about the new world after a major catastrophe has decimated the Earth. The book written by Veronica Rossi is a young adult debut novel in a trilogy. The story is about Aria, a 17 years old girl who has been living in domed city or Pod called Reverie and Peregrine, a 18 years old boy who has been lived outside domed city called Death Shop. Reverie looks like a modern world inside dome. Everyone lives happily use high technology, even the nature condition can make. In other situation but in same world, Death Shop has opposite condition with Pod. it is the primitive place where people lives with the jungle role. Someone can get anything when he was strong and hold the power. Outsiders have work in land and hunt to get food.

The conflict came when Aria as the main character exiled from Reverie. She has to survive in Death Shop, known as a place that filled with cannibals and terrible Aether storms, The air even can kill. Aria met Peregrine and make deal to help each other. Peregrine need Aria to enter Pod because he must save his nephew that was kidnapped by Dweller. Likewise, Aria needs Peregrine to help her survive in Death Shop, so she can back to Pod to meet her mother. They pass many dangers to reach their direction. Long time in outside makes Aria knows who she is. She adapts and learns from nature in Death Shop. Aria and Peregrine realize the different nature condition in Death Shop and Pod although they live in same world.

This study will explore the portrayal of Reverie as a domed city and Death Shop as a wasteland using Garrad's perspective. Both characters live in two different places in same worlds have their own ways to survive and interact with nature.

\section{REVIEW OF LITERATURE}

\subsection{Ecocriticism}

In The Ecocriticism Reader : Landmark in Literary Ecology, Cheryll Glotfelty and Harold Fromm explain about the definition of ecocriticism asoikos and kritos mean "house judge". A long winded gloss on ecocrit might run as follow: " a person who judges the merits and fault of writings that depict the effects of culture upon nature with a view toward celebrating nature, berating its despoilers, and reversing their harm through political action." The Greek oikos, household, and in modern usage refers both to "the study of biological interrelationships and the flow of energy through organisms and organic matter." (1996:62) So, the oikos is nature, a place Edward Hoagland call "our widest home," and the kritos is an arbiter of taste who wants the house kept in good order, no boots or dishes strewn about to 
ruin the original decor. (Buell, 2005:13). Simply put, ecocriticism is the study of the relationship between human who kept nature with poured in literature and the physical environment.

Greg Garrard in his book "Ecocriticism" explain Ecocriticism is the study of the relationship of human and the non-human, throughout human cultural history and entailing critical analysis of the term 'human' itself (Garrard, 2004:5). Ecocriticism tries to examine and evaluate text and idea with relation to environmental issue.

Ecocriticism is interdisciplinary, calling for collaboration between natural scientists, writers, literary critics, anthropologists, historians, and more. Ecocriticism asks us to examine ourselves and the world around us, critiquing the way that we represent, interact with, and construct the environment, both "natural" and manmade. At the heart of ecocriticism, many maintain, is "a commitment to environmentality from whatever critical vantage point" (Buell,2005:11). In this age of environmental crisis it is enlightening to analyse the works of this well-known writer against the backdrop of eco-critical theories which take an earthcentred approach to literary studies.

Ecocriticism's attention to place reflects its recognition of the interconnectedness between human life/history and physical environments to which works of imagination (in all media, including literature) bear witness - hence the claim by one of ecocriticism's earliest spokespersons that its distinctive addition to the commonly studied triad of race, class, and gender was place as a critical category (Buell, Heise and Thornber, 2011:420).

\subsection{Concepts of Ecocriticism}

The concept of ecocriticism are:

\section{Pastoral}

Pastoral is a good example for examining human-nature relationship representation of the physical world. Pastoral, undoubtedly one of the most universal forms of Western environmental imagination has become almost synonymous with the idea of return to a less urbanized, more natural state of existence (Buell, 2005: 31). This concept of ecocriticism directs to portray of nature in physical world, sometimes in ways to care with environment and protect nature. In dystopian literature, Pastoral sometimes is described as the other part of world or place where the character can escape from the damaged world. It can be destruction of nature or human's moral.

Pastoral is much found in British and American literature, focuses on the dichotomy between urban and rural life (Garrard, 2004: 33). At the forefront of works which display 
pastoralism is a general idealization of the nature and the rural and the demonization of the urban. Often, such works show a retreat from city life to the country while romanticizing rural life, depicting an idealized rural existence that "obscures" the reality of the hard work living in such areas requires (2004:33). According to Garrad, in classical period of pastoral creates two key contrasts: the spatial distinction of town and country as well as a temporal distinction of a fallen present and an idyllic past (2004:35). It presents the distinction of town (frenetic, corrupt, impersonal) and country (peaceful, abundant) in fallen present.

Greg Gerrard identifies three branches of the pastoral. First, Classic Pastoral, "characterized by nostalgia" (2004:37) and an appreciation of nature as a place for human relaxation and reflection. Second, Romantic Pastoral, a period after the Industrial Revolution that saw "rural independence" as desirable against the expansion of the urban. Third, American Pastoralism, which "emphasized agrarianism" (2004:49) and represents land as a resource to be cultivated, with farmland often creating a boundary between the urban and the wilderness.

\section{Wilderness}

Wilderness is the natural, unfallen antithesis of an unnatural civilization that has lost its soul. It is a place of freedom in which we can recover our true selves we have lost to the corrupting influences of our artificial lives. Most of all, it is the ultimate landscape of authenticity (Cronon, 1996: 80). Wilderness also share the sense of "undomesticated." Literally, wilderness refers to a spatial area, whereas wildness is a term of quality rather than location. Wildness is arguably "everywhere: ineradicable populations of fungi, moss, mold, yeasts, and such that surround and inhabit us" (Snyder,1990: 14).

Wilderness is represented in literature and popular culture. Representations of wilderness in British and American culture can be separated into a few main tropes. First, Old World wilderness displays wilderness as a place beyond the borders of civilization, wherein wilderness is treated as a "threat," a place of "exile" (Garrard, 2004: 62). This trope can be seen in Biblical tales of creation and early British culture. Old World wilderness is often conflated with demonic practices in early American literature.

Second, New World wilderness, seen in portrayals of wilderness in later American literature, applies the pastoral trope of the "retreat" to wilderness itself, seeing wilderness not as a place to fear, but as a place to find sanctuary. The New World wilderness trope has informed much of the "American identity," and often constructs encounters with the wilderness that lead to a more "authentic existence" (2004:71). Besides wilderness known as 
a land of dangerous and share sense of undomesticated, it also refer to sacral place to get freedom and place to escape from pollution of the city. Wilderness reinvigoration of those tired of the moral.

\section{Apocalypse}

Greg Garrard points out in his chapter entitled "Apocalypse," the realization that the world is notabout to end, and that human beings - namely contemporary youth - like the environment, are likely to survive even if our constructed civilization does not (Garrard, 2004: 107). Garrard suggests, apocalypse involves a 'social psychology' that inclines towards 'paranoia and violence', 'extreme moral dualism', and canonisation of 'believers'; and because it is always been coming yet, it is always an imaginative act (2004:107).This definition suggests the following features: the social psychology of apocalypticism that has historically inclined such 'embattled' movements to violence. The extreme moral dualism that divides the world sharply into friend and enemy. The emphasis upon the 'unveiling' of historical truth and the corresponding role of believers as the ones to whom, and for whom, the veil of history is rent. But most importantly, apocalypticism is inevitably bound up with imagination, because it has yet to come into being.

In this point, ecocriticism's concept (Pastoral, Wilderness and Apocalypse) will be used to analyze the representation of nature that appear in Under the Never Sky novel. The interaction of Aria and Peregrine with natural environtment will be taken as the data obtained from the novel.

\section{DISCUSSION OF THE MAIN THEMES}

\subsection{Representation of Nature in Under the Never Sky}

The analysis is carried out based on some dominant concepts namely wilderness, pastoral, and apocalypse.

\section{Pastoral}

The portrayal of pastoral is shown by two different places in Under the Never Sky novel, they are Pod and Death Shop. Pod represents a town described as a frenetic, corrupt, and impersonal. Meanwhile, Death Shop represents a country known as peaceful and abundant.

As a representation of a town, Pod is known as the domed city that protects people from outside. Most of Pods is aboveground, sheltered under the dome and surrounded by walls. One of Pod where Aria lives called Reverie. It contains the modern building, intellectual 
society and high technology development, 'most everything, from the production of food to the recycling of their air and water, was automated.'(Rossi, 2012: 304).

Inside the Pod, nature is present in two ways. First, through illusion using Smarteye. Developing technology in Reverie creates the clear device called Smarteye. It is worn over the left eye and it was always on. The Eye took Dwellers to the Realms. "Realms are virtual places. They're places as real as this is. If my Smarteye was working, I could go to any part of the world and beyond too, from right here. Without going anywhere.” (Rossi, 2012: 175). The Realms allow them to visit any place everywhere and every nature condition. The Realms are the copy of world contains many places and many things like earth. Plants in Realms are artificial because Smarteye helps stimulate brain to be able to see and feel something with more live and real. 'In the Realms food still grew, or pretended to grow virtually, on farms with red barns and fields under sunny skies' (Rossi, 2012: 14).

The Second way, nature present inside the pod is through service dome called Agriculture 6. Dozens of domes supply Reverie with food, water, oxygen and all the things an enclosed city need. Ag 6 looks like a cavernous space. 'The real food in Ag 6 looked like old people before aging-reversal treatments. The food grew from waist-high plastic mounds' (Rossi, 2012:13). The real plants in Agriculture 6 looked liked old people, wrinkling and lacking brightness.

On the other hand, the portrayal of country is Death Shop. Country is described as the peaceful place which has abundant nature contains stretch of valley, desert, hills, sea and forest like earth should be. The only difference is the earth is more polluted and the sky contains Aether's storms. Aether is part of Death Shop and a form of representation of nature in the novel where the cloudy skies are supposedly made from evaporation of water transformed into flames and water. The sky was blazing with deep blue mixed thick gray clouds. Aether flows over a clump of clouds gathered into a thick and bright current.

Death Shop also has season like spring where flowers bloom. 'Spring sang its chattering music into Aria's ears. Flowers burst up all along the wall, the colors bright against the gray stones. Winter had left broad bare spots on the mountain and the smell of smoke in the air' (Rossi, 2012: 485). Death shop more generally looks like the real earth without Aether storm.

\section{Wilderness}

There are two kind of Wilderness in Under the Never Sky novel. The wilderness of society in both Pod and Death Shop and the wilderness of Death Shop's land. 
First, land of Death Shop represents the untamed landscape. It is a place with a million ways to die. Aria as the main character has bad experience when she is thrown to Death Shop. "She'd heard all the stories about the Death Shop, like everyone else. A million ways to die. She knew of the packs of wolves as smart as men. She'd heard of the flocks of crows that picked living people to pieces, and Aether storms that behaved like predators” (Rossi, 2012: 89). For the first time, Aria feels danger in every steps in thenew world. The different culture and nature makes Aria afraid and odd in the untamed place. Since she had been thrown out of Reverie, she had met an Aether storm, had had knife held to her throat by a cannibal, and had seen men was murdered and pursued by group of wolves.

Second, through technology human can save or destroy nature. In Reverie dome, Dwellers choose to stop connecting with nature and the outside world. They can not go anywhere. This situation makes genetic experts try to create a virtual world with Smarteye;a world with no fear and no pain. They are only in place of pseudo-visualized as real named Realms. The existence of Smarteye makes Dweller can do two things at once without the need to move. The dangerous situation came when the region is inaccessible, and the risks is the emergence of a new disease called Degenerative Limbic Syndrome (DLS). The desease makes the Dwellers crazy, so that Chaos spreads throughout the pod. 'Aria pressed her eyes closed, fighting the image of the chaos in Ag 6 on a grand scale. A Pod-wide riot where her mother was. A thousand people starting fires and ripping off Smarteyes' (Rossi, 2012: 342). Situation got worse by time. Many Dwellers are crazy and their behavior becomes uncontrollable. The pod that was once filled with moral and educated people became a chaotic and dangerous place. The only safe place on earth also has another dreadful danger.

Meanwhile, the Outsiders has direct relation with nature. They live as part of nature and they have their own action to survive and adapt in harsh environment. Sometimes, the behavior of outsiders is influenced by nature itself, and it is not always in a good way. The natural environment outside Pod is dangerous, whichonly the strong people will survive. One of the tribes is called the cannibal tribe, the Croven tribe, "The Fins were already weakened when illness hit them in the open. Then the Croven came and took the strongest children into their fold. To the rest ... well, they did what the Croven do." (Rossi, 2012: 308). The Croven tribe chooses the bad way to survive in dangerous nature. They are known for their cruelty to slaughter the tribe and oppress the weak people. They survive with eat anything including humans.

The wilderness hold unpredictable dangers, nature is not always in good side to escape. The danger also exist in a place looks beautiful and peaceful like in the Death Shop. The 
cultural wilderness is also shown in the urban and rural society. In the Pod, society become dangerous because the pseudo-earth called Realms. Meanwhile in the Death Shop, there is Croven tribe as a cannibal tribe. They sacrifice other tribes to survive.

\section{Apocalypse}

Apocalypse seems to be the common setting time and place in young adult dystopian novel. Under the Never Sky takes imagination place which may exist on earth after the union period. The place is divided into two, that are world Pod and Death Shop. Apocalypse is equated with foreboding doom and human eradication. The apocalypse in the novel is where human thinks that the end of world will come soon. The doomday cames in two ways: human and nature power.

The proof that nature has its power is the aether storms. The storm gets worse and ruins many places. "Bliss was struck by an Aether storm. They said it was destroyed" (Rossi, 2012: 310). Pod of Dweller named Bliss was damaged by aether storm. Not only Pod, Aether storm also burns the western plain of the Death Shop included the Blackfin tribe who live in the plain. Aether storms came and hit their compound directly. 'The Blackfin compound looked nothing like the bustling settlement he'd seen a year ago. Now, it was crushed. Abandoned. All its scents faded and old. A picked-over carcass at the foot of Mount Arrow.' (Rossi, 2012: 204). Because of the aether stormwhich is growing worse every winter and scorching anything, the inhabitants couldn't stay for much longer.

Apocalypse in the novel is the imagination of a sense crisis. Lumina, Aria's mother explains another part of doomsday because of the new disease. Actually, the new disease has not yet coming and infecting all Dwellers. Only some of Pods was fall in the disease. The crisis is the cause of human power.No one knows the solution to save themselves from the six thousand people who live inside the enclosed dome with a mental disorder syndrome. 'We're left in dire situations that we're incapable of handling. Entire Pods have fallen to DLS' (Rossi, 2012: 339). This causes a precarious situation. All pods are infected with DLS outbreaks in short time. The pain and pleassure emotion confused. Bliss becomes the first place in Pod infected the disease. People are caged and contracted this syndrome. Damage, violence and even massacres may occur as a result of this syndrome. So that doomsday has just begun.

The imagination of doomdays in Pod and Reverie appears because the nature and human power. The apocalypse setting is shown after the Unity period when the aether storms can shatter anything and the disease destroy civilization. 
In conclusion, there are two concepts of Garrad's persepective to analyze the representation of nature in any condition. First, nature and human has deep relationship. Representation of nature depend on human action. Human can destroy or save nature. Besides, Nature also has their own power to makes human sometimes need to survive. The nature and surroundings show that every human has their own way to survive with adaptation on nature power.

\subsection{The Interaction of Aria and Peregrine with Nature}

This part will explain how the interaction of main characters, Aria and Peregrine, with nature, such as getting knowledge about nature and having relation with nature.

\section{Aria}

Aria is a 17-year-old girl living in an enclosed pod named Reverie. For 17 years, she lived in a closed place without knowing what is out there. Aria's interaction with the outside world is severely restricted. She feels comfortable and save in the pod. Nothing or no one can hurt her physically or emotionally. Environment's rules in the Reverie makes everyone has the same position and get same needs. Everyone lives happily because they have Smarteye and Realms.

Aria has many experiences with nature, not only virtual things in the Realms but also in the real place in the Death Shop. In outside dome, Aria sees real plant grows in the soil, and forest was filled by tall trees. She can touch the real tree. 'It was cooler and darker under the trees. Aria ran her free hand over the trunks, feeling the rough textures' (Rossi, 2012: 20).

In Death Shop, Aria learns how to survive. She knows how to get water when she is in dried land or desert. She has to dig the land. 'She had a fair idea now how hard his life was, if finding a drink of murky water took an hour's worth of digging' (Rossi, 2012: 185). Aria really likes learning about the new environment in the Death Shop. She asks many things and gets information from Peregrine about nature. She feels fantastic with what she sees and finds in Death Shop because nature feels different than in the Realms.

In addition, Aria learns to spin the branches to make shelter and retaining from the wind. 'Aria copied the way they wove the branches together and found that for her first-ever screen, she did a respectable job' (Rossi, 2012: 233). The next day she spends hours thinking and turning her inquisitiveness inward. She likes what she was discovering about herself. Aria, who knew that birds should be plucked while they were still warm so the feathers come out more easily. 
A long journey takes Aria to know the truth about her, that she is also a marked person, just like Peregrine and Roar. 'He was an Audile. That was the only thing she knew about him. Strangely, it felt like a lot' (Rossi, 2012: 443). Aria is a half Outsider. Her father is an Audile and that ability is down to Aria. Her half-hearted Outsider explained why Aria did not die in the Death Shop and infected with a DLS outbreak like most Dweller.

The proof Aria relates with nature is her ability as Audile. The presence of Aether makes people were 'marked'. In the Realms, Aria's ability cannot be developed because of the nature condition. In the safe place, she never uses her instinct to survive, but in the Death Shop she met many dangerous situation every times. Without using her instinct to make quick decision or called reflex, she cannot survive and get their ability.

\section{Peregrine}

Peregrine or Perry is an 18-year-old boy who lives outside the pod. He is an Outsider. He knows better than anyone about danger in the Death Shop. He spends his entire life there, learns how to live in the Death Shop. Perry is very dependent on nature. He uses nature to survive. Food is available in nature. He eats from what nature provides. He hunts and plants crops. 'Perry spent the morning adjusting to the change and searching for game trails' (Rossi, 2012: 220). Perry is a great hunter.

Life in the Death Shop makes Perry feels familiar with the dangerous nature. Perry has many common experiences about the difficult life in the Death Shop. But, his desire to find her nephew brought Perry into Realms, a virtual world where Aria spends her time. Perry must use Smarteye to enter the Realms. Perry gets new experience with different nature condition in the Realms. The first experience is awkward and embarrassing. The forest before him was blurred and the surrounding trees were like running. It is his first time that he knows another world. The all things should be in the forest are vanished, like smell. He cannot smell anything. His senses are blunt because he is in a virtual space.

Perry's arrival in the Realms makes him realize and know something about that place. This is a simple and practical place where Aria lives and spends their time. It is the same world with different nature and culture condition.He gets many new things to learn to be able to adapt in the Realms. 'They brought up the forest again. The images battled for his attention like before, but Perry imagined aiming at a curled piece of bark that shuddered past. The woods fixed around him, bringing a sudden, shocking stillness' (Rossi, 2012: 357). The young boy cannot smell the traces of animals or mushrooms even though there were dozens of mushrooms on the trees. 
Nature related to outsider perfectly. Most of outsider lives in the Death Shop is marked people. It means aether flow in their blood makes them have special ability to survive in hard nature condition. Likewise with perry, Aether flows in Perry blood makes him marked. Among the marked people, Perry is including the rare. He has two dominant senses. Perry is a Scire who has a keen sense of smell but only Scire as strong as Perry can smell the mood. As a Seer he saw better. Most Seers look at during the day but Perry real strength lay in seeing in the dark. 'As a Seer, he made a skilled archer. But only Scires with noses as strong as Perry's could breathe and know despair or fear. Useful things to know about an enemy, but when it came to family felt more like a curse'. (Rossi, 2012:52)

In conclusion, Aria and Peregrine as the main characters have their own action to adapt and survive in the nature. In the beginning, both of them rejects the different situation of nature. However, they have to interact with nature, like Aria learns to survive in the Death Shop or Perry goes into Realms to save his nephew.

\section{CONCLUSION}

The dystopian novel, Under the Never Sky by Veronica Rossi, presents dystopian setting in place and time. To some extent, nature appear in different landscape. Using Garrad's persepective in ecocriticism, nature is represented in three concepts. Pastoral, Wilderness and Apocalypse.

First, the representation of nature is the Pastoral. It tells and shows natural environment including place and society in novel. There are two places in the novel which have different nature condition, they are Pod and Death Shop. Pod is the domed city where Aria lived. Pod is the representation of town. Pod imitates nature and environment through Smarteye - the clear device - which took Dweller to virtual space called Realms. Pod restricts contact with outside because the Aether so Dweller makes Realms. Meanwhile, Death Shop is the place outside Pod where Peregrine lived. It is the representation of country. The landscape contains the forest, river, desert, and hill. Besides, Death Shop was famous with the dangerous place. In the Death Shop water is coated with foam or reeking of dead fish and Aether storms that behaved like predators. Aether makes some of Outsider 'marked' to get dominant sense. The portrayal of Pastoral explains the nature and society condition in novel.

Second, the wilderness is mostly experienced by the dangerous place or situation. Aria and Peregrine have to survive in Death Shop and Realms to get their purpose. Wolves, toxic berries, cannibal tribe, aether, and crazy syndrom appear as wilderness in the novel. 
Third is apocalypse. It expresses the doomdays, the imagination of the end of the world that will happen someday. It can happen because human or nature power which makes decision to destroy and end the world. In this case, the novel presents both of them as the cause of doomdays.

Interactions between Aria and Peregrine with nature in Under the Never Sky novel illustrate that eventhough nature is sometimes fortuitous and dangerous, but it always inseparable with humans.Aria and Peregrine expresses that nature as a peaceful place where their thoughts can be free, even though Aria has bad experience when she was thrown to Death Shop for the first time but she can adapt with nature as the times goes by. She is really interested in learning about nature, how to make fire, learn about toxic and medicinal plants and so on. In nature Aria knows that she is a half Outsider. She gets blessed 'marked' as Audile (sense of hearing). Peregrine too, he lives in Death Shop in a whole of his life. He learns with nature how can use his ability as scire (sense of smell) and Seer (sense of seeing). As a marked person, he is a reliable hunter and fighter. Peregrine can feel aether strom movement.

Thus, Under the Never Sky clearly shows the futuristic future in enviromental issues. Examining the text demonstrates the different ways of someone have imagined the future of our planet. It is important for young adults to engage with these young adult dystopian texts, not just as literary reading experiences, but also because they offer an environmental warning with a hope.

\section{REFERENCES}

Basu, et al. (Ed). (2013). Contemporary Fiction for Young Adults Brave New Teenagers. London: Routledge.

Buell, L. (2005). The Future of Environmental Criticism : Environmental Crisis and Literary Imagination. USA : Blackwell Publishing.

Buell, L.,Ursula K. H., \& Karen T. (2011 November). Literature and Environment. Annual Review of Environment and Resources, 36, 417-440.Retrieved March 11, 2011 from http://www.annualreviews.org/doi/abs/10.1146/annurev-environ-111109-144855

Cronon, W.(1996)"The trouble with wilderness; or, Getting back to the wrong nature."Uncommon Ground: Rethinking the Human Place inNature. London: Norton.

Cuddon, J. A., \&Claire, P. (1999). "Utopia”The Penguin Dictionary of Literary Terms and Literary Theory. London: Penguin.

Garrard, Greg. (2004). Ecocriticism. New York: Routledge. 
Glotfelty, C.,\& Harold,F. (1996).The Ecocriticism Reader: Landmarks in Literary Ecology. Athens and London: The University of Georgia Press.

Rossi, V. (2012). Under the Never Sky. New York: HarperCollins Publisher Inc.

Snyder, G.(1990). The Practice of the Wild. San Francisco, CA: North Point. 